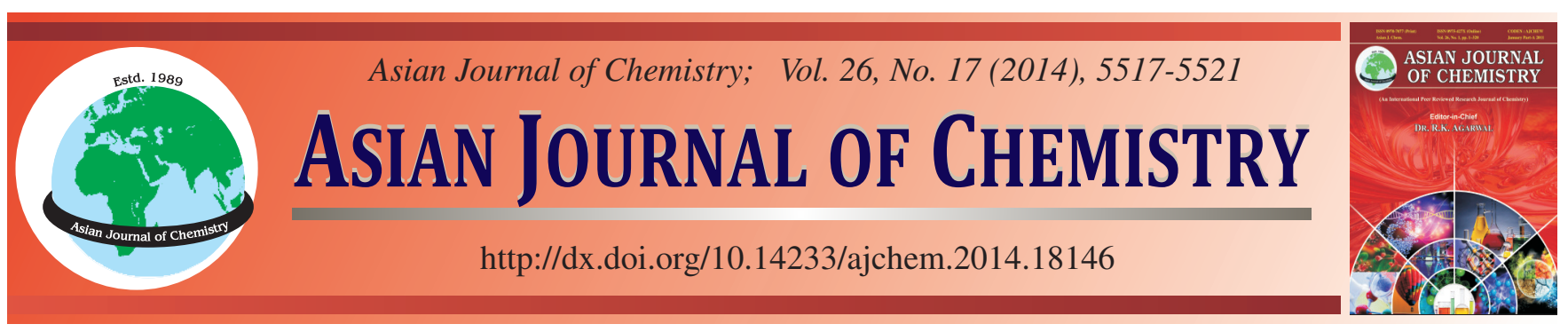

\title{
Mechanical Performance of Fly-Ash-Based Green Geopolymer Composites Subjected to Elevated Temperatures $\dagger$
}

\author{
Y.C. CHOI ${ }^{1}$ J.H. $\mathrm{KIM}^{1}$ and S. $\mathrm{CHOI}^{2, *}$
}

${ }^{1}$ High-Tech Construction Materials Center, Korea Conformity Laboratories, Seoul, Republic of Korea

${ }^{2}$ Department of Civil and Environmental Engineering, Chung-Ang University, Seoul, Republic of Korea

*Corresponding author: Fax: +82 2 8126397; Tel: +82 2 8205303; E-mail: schoi@cau.ac.kr

This paper discusses the effect of $\mathrm{Na}_{2} \mathrm{O}$ content, $\mathrm{SiO}_{2} / \mathrm{Na}_{2} \mathrm{O}$ mole ratio and elevated temperature on the mechanical performance of flyash-based inorganic green geopolymer composites. Fly-ash-based geopolymers, which were manufactured with varying alkali contents (4-8 \% of fly ash weight) and $\mathrm{SiO}_{2} / \mathrm{Na}_{2} \mathrm{O}$ mole ratios (0.6-1.4), were subjected to elevated temperatures up to $900{ }^{\circ} \mathrm{C}$. The geopolymer composites and their performance were evaluated on the basis of weight loss and strength loss after temperature exposure. In addition, mineralogical changes due to the elevated temperature exposure were studied using X-ray diffraction. Investigation of microstructures as well as microprobe analysis was performed using scanning electron microscopy, Fourier-transform infrared spectroscopy and mercury intrusion porosimetry. The results showed that the fly-ash-based geopolymer responded significantly to high temperature conditions.

Keywords: Elevated temperature, Fly-ash-based geopolymer, Mechanical performances.

\section{INTRODUCTION}

Geopolymers are an alternative to portland cement that can be used to produce concrete without the considerable carbon dioxide emissions. Among the alumino-silicate materials, metakaolin and fly ash are the most favorable raw materials for geopolymer production. However, metakaolin-based geopolymer has limited availability and high cost. Therefore, most of the recent research on geopolymer uses fly ash as the binder ${ }^{1-4}$.

Dissolution of the solid alumino-silicate source by alkaline hydrolysis produces aluminate and silicate species. The dissolution process is rapid at a high $\mathrm{pH}$ and this quickly creates a supersaturated alumino-silicate solution. In concentrated solutions, this process results in the formation of a gel, as the oligomers in the aqueous phase form large networks by condensation. After gelation, the system continues to rearrange and reorganize, as the connectivity of the gel network increases, resulting in the three-dimensional alumino-silicate network commonly attributed to geopolymers. These processes of structural reorganization determine the microstructure and pore distribution of the material, which are critical in determining many physical properties ${ }^{5-8}$.

The dissolution process starts with an attack to the flyash particles by the alkaline solution ${ }^{9-15}$. As a result, the reaction product is generated both inside and outside the individual cells until the ash particle is completely or almost completely consumed. At the same time, reaction products are created as the alkaline solution penetrates the larger sphere and fills up the interior space with reaction products, forming a dense matrix. Due to the massive precipitation of reaction products, some smaller particles are covered with the products, forming a crust that prevents contact with an alkaline solution, resulting in an unreacted fly ash particle.

The existing studies investigated the superior heat resistance of geopolymers, which are reactant products of sodium silicate and potassium silicate with metakaolin that demonstrate thermal stability up to $1200-1400^{\circ} \mathrm{C}$. These materials contain "ceramic-like properties"10,11. The thermal behaviour of flyash-based geopolymers, however, has not been sufficiently investigated, although the favorable characteristics-such as the increase in strength and fire resistance-are expected when geopolymers are exposed to elevated temperature. The present research focuses on determining the influence of high temperatures (ranging from $80-900{ }^{\circ} \mathrm{C}$ ) on the properties of geopolymer materials based on low-calcium fly ash from Korea. This study also investigates the effect of elevated temperature exposure on the geopolymer pastes and aggregate composites (geopolymer concrete). 


\section{EXPERIMENTAL}

Fly ash is the alumino-silicate material used in the synthesis of geopolymeric binder in this research. The chemical composition of the sodium silicate solution is shown in Table- 1 . The low-calcium fly ash used in this experiment was sourced from the Namdong power plant in Korea. Its mineral and chemical compositions are shown in Table-2. The specific gravity was $2.42 \mathrm{~g} \mathrm{~cm}^{-3}$ and Blaine specific surface was $4,013 \mathrm{~cm}^{2} \mathrm{~g}^{-1}$. The fly ash's particle size distribution is illustrated in Fig. 1.

\begin{tabular}{cccc}
\multicolumn{3}{c}{ TABLE-1 } \\
\multicolumn{5}{c}{ CHEMICAL AND PHYSICAL PROPERTIES } \\
OF LIQUID SODIUM SILICATE \\
\hline $\begin{array}{c}\mathrm{Na}_{2} \mathrm{O} \\
(\%)\end{array}$ & $\mathrm{SiO}_{2}$ & $\begin{array}{c}\mathrm{SiO}_{2} / \mathrm{Na}_{2} \mathrm{O} \\
(\text { wt. ratio })\end{array}$ & $\begin{array}{c}\text { Density } \\
\left(20^{\circ} \mathrm{C}, \mathrm{g} \mathrm{cm}^{-3}\right)\end{array}$ \\
\hline 9.18 & 29.11 & 3.17 & 1.40 \\
\hline
\end{tabular}

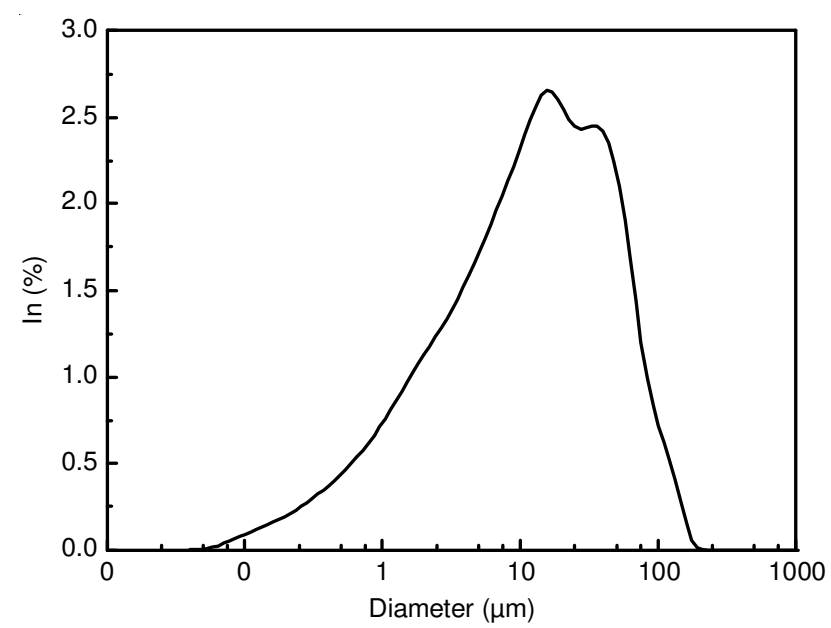

Fig. 1. Particle size distribution of fly ash

Goepolymer paste: In this study, two series of geopolymer paste samples were made, differing in their composition. In series 1 , samples were prepared using a sodium hydroxide/ sodium silicate solution, providing $6 \%$ sodium (weight $\%$ by fly ash) in mixtures and $\mathrm{SiO}_{2} / \mathrm{Na}_{2} \mathrm{O}$ mole ratio of 0.6-1.4 (mix No. 1-6). In series 2, the prepared samples provided a $1.0 \mathrm{SiO}_{2} /$ $\mathrm{Na}_{2} \mathrm{O}$ mole ratio and 4-8 \% $\mathrm{Na}_{2} \mathrm{O}$ (mix No. 6-7) in mixtures. The liquid/solid ratio of all samples is 0.55 . The mix proportions of the geopolymer paste are shown in Table- 3 . The mould size used was $50 \mathrm{~mm} \times 50 \mathrm{~mm} \times 50 \mathrm{~mm}$. All samples were cured undisturbed for $24 \mathrm{~h}$ at room temperature before being subjected to high temperature curing $\left(80^{\circ} \mathrm{C}\right.$, relative humidity of $95 \%$ ) for another $24 \mathrm{~h}$ in a chamber. At the end of the curing regime, the samples were removed from their moulds and allowed to cool before mechanical tests were performed.

Post-thermal test: An electrically heated furnace designed for a maximum temperature of $1200{ }^{\circ} \mathrm{C}$ was used. Samples were subjected to temperatures of up to $900{ }^{\circ} \mathrm{C}$ at an incremental rate of about $5{ }^{\circ} \mathrm{C} / \mathrm{min}$ from room temperature inside the furnace. All the samples were mechanically characterized to evaluate the residual strength after abrupt but not prolonged exposure to high temperatures, in an attempt to simulate the conditions prevailing in the event of accidental fire. Test samples were subjected to strong thermal shock by placing them directly inside a furnace at different temperature $(300,600$ and $900{ }^{\circ} \mathrm{C}$ ). They were subsequently kept in this high temperature for $2 \mathrm{~h}$ and then exposed to ambient temperature.

In addition, the raw materials as well as the samples tested under post-thermal conditions were analyzed using thermogravimetric/differential thermal analysis, X-ray diffraction, Fourier-transform infrared spectroscopy and mercury intrusion porosimetry.

\section{RESULTS AND DISCUSSION}

Compressive strength of geopolymer pastes: The compressive strength of each sample after exposure to different temperatures was compared to an unheated sample's strength. The strength changes are shown in Tables 4 and 5. The results indicate that the samples prepared at $\mathrm{SiO}_{2} / \mathrm{Na}_{2} \mathrm{O}$ mole ratio of $0.6,0.8,1.0,1.2$ and 1.4 had a tendency to increase in strength. As the temperature exposure increased from 300 to $900{ }^{\circ} \mathrm{C}$, the samples' strength values increased as well. In considering the effects of $\mathrm{Na}_{2} \mathrm{O}$ on the samples, the researchers noted that the higher the $\mathrm{Na}_{2} \mathrm{O}$ content, the greater the compressive strength increases. Also, the effect of high temperature exposure (300$900{ }^{\circ} \mathrm{C}$ ) showed a trend similar to that of the effect of $\mathrm{SiO}_{2} /$ $\mathrm{Na}_{2} \mathrm{O}$ mole ratio.

Visual change of geopolymer pastes: The samples displayed significant colour change during exposure to the higher temperatures. After exposure to $300{ }^{\circ} \mathrm{C}$, the samples had no distinctive colour changes, remaining the dark grey of the original sample colouration. After exposure to $600^{\circ} \mathrm{C}$, the colour changed to lighter grey. The colour then impressively changed at $900^{\circ} \mathrm{C}$ to red, accompanied by a ceramic-like surface texture.

Microstructures of geopolymer pastes: The XRD and FTIR techniques were used to acquire a better understanding of the possible transformations in the untreated samples as well as in the samples subjected to post-thermal tests as a result of exposure to high temperatures. The present analysis focussed on the description and interpretation of the changes observed

\begin{tabular}{|c|c|c|c|c|c|c|c|c|c|c|}
\hline \multicolumn{11}{|c|}{$\begin{array}{c}\text { TABLE-2 } \\
\text { CHEMICAL COMPOSITION OF THE FLY ASH USED }\end{array}$} \\
\hline Chemical component & $\mathrm{CaO}$ & $\mathrm{SiO}_{2}$ & $\mathrm{Al}_{2} \mathrm{O}_{3}$ & $\mathrm{Fe}_{2} \mathrm{O}_{3}$ & $\mathrm{MgO}$ & $\mathrm{K}_{2} \mathrm{O}$ & $\mathrm{Na}_{2} \mathrm{O}$ & $\mathrm{SO}_{3}$ & $\mathrm{LOI}^{\mathrm{a}}$ & Total \\
\hline Weight (\%) & 4.42 & 56.00 & 24.00 & 5.39 & 1.44 & 1.38 & 1.00 & 0.19 & 4.80 & 98.62 \\
\hline
\end{tabular}

\begin{tabular}{|c|c|c|c|c|c|c|c|c|}
\hline \multicolumn{9}{|c|}{$\begin{array}{c}\text { TABLE-3 } \\
\text { MIXING PROPORTIONS OF GEOPOLYMER PASTES }\end{array}$} \\
\hline Mix number & 1 & 2 & 3 & 4 & 5 & 6 & 7 & 8 \\
\hline $\mathrm{Na}_{2} \mathrm{O}$ content $(\%)$ & 6 & 6 & 6 & 6 & 6 & 4 & 6 & 8 \\
\hline $\mathrm{SiO}_{2} / \mathrm{Na}_{2} \mathrm{O}$ mole ratio & 0.6 & 0.8 & 1.0 & 1.2 & 1.4 & 1.0 & 1.0 & 1.0 \\
\hline
\end{tabular}




\begin{tabular}{|c|c|c|c|c|c|}
\hline \multirow{4}{*}{$\begin{array}{l}\text { Post-thermal } \\
\text { condition }\end{array}$} & \multicolumn{5}{|c|}{$\begin{array}{l}\text { TABLE-4 } \\
\text { THERMAL TEMPE }\end{array}$} \\
\hline & \multicolumn{5}{|c|}{ Compressive strength (MPa) } \\
\hline & \multicolumn{5}{|c|}{$\mathrm{SiO}_{2} / \mathrm{Na}_{2} \mathrm{O}$ mole ratio } \\
\hline & 0.6 & 0.8 & 1.0 & 1.2 & 1.4 \\
\hline- & - & 5.5 & 13.2 & 17.0 & 19.7 \\
\hline $300^{\circ} \mathrm{C}$ & 6.5 & 9.8 & 20.3 & 28.3 & 35.1 \\
\hline $600{ }^{\circ} \mathrm{C}$ & 8.0 & 14.7 & 38.0 & 40.7 & 48.2 \\
\hline $900{ }^{\circ} \mathrm{C}$ & 18.9 & 33.1 & 49.1 & 52.8 & 66.6 \\
\hline
\end{tabular}

\begin{tabular}{cccc} 
& \multicolumn{2}{c}{ TABLE-5 } \\
EFFECTS OF Na & $\mathrm{O}$ CONTENT AND POST-THERMAL \\
TEMPERATURE ON COMPRESSIVE STRENGTH \\
\hline \multirow{2}{*}{$\begin{array}{c}\text { Post-thermal } \\
\text { condition }\end{array}$} & \multicolumn{3}{c}{ Compressive strength (MPa) } \\
\cline { 2 - 4 } & \multicolumn{2}{c}{$\mathrm{Na}_{2} \mathrm{O}$ content (\% by wt. of fly ash) } \\
\cline { 2 - 4 } & $4 \%$ & $6 \%$ & $8 \%$ \\
\hline- & - & 13.1 & 32.2 \\
$300^{\circ} \mathrm{C}$ & 3.9 & 24.3 & 47.8 \\
$600{ }^{\circ} \mathrm{C}$ & 8.0 & 30.1 & 54.7 \\
$900^{\circ} \mathrm{C}$ & 17.2 & 49.2 & 75.2 \\
\hline
\end{tabular}

$\mathrm{SiO}_{2} / \mathrm{Na}_{2} \mathrm{O}$ mole ratio $=1.0$; liquid-solid ratio $=0.55$.

in the mineralogy and microstructure of materials made with alkali-activated fly ash.

Fig. 2 shows the diffractograms for the original fly ash and the geopolymer paste matrix after the high temperature tests. The majority of crystalline phases present in the initial ash (quartz and mullite) were barely affected by the activation process or exposure to high temperature. The halo characteristic of the vitreous phase in the initial ash (located in the $20-30^{\circ} 2 \theta$ range) shifted to $2 \theta$ values of $25-30^{\circ}$ as a result of alkaline activation. This shift is indicative of the formation of an alkaline alumino-silicate gel as the main reaction product, which may be a determining factor in temperature-induced strength change. Slight changes in intensity are observed in this halo with rising temperatures but are difficult to quantify. Zeolites formed as secondary reaction products. Hydroxysodalite $\left(\mathrm{Na}_{4} \mathrm{Al}_{3} \mathrm{Si}_{3} \mathrm{O}_{12} \mathrm{OH}\right)$ formed in the initial geopolymer paste matrix as a minority crystalline phase during activation. In a sufficiently alkaline medium, hydroxysodalite is so thermodynamically stable that it crystallizes fairly quickly and easily.

In this study, the FTIR spectra of samples (Fig. 3) were acquired using an Avatar 36 FTIR Spectrometer in absorbance mode within the frequency range of $4000-400 \mathrm{~cm}^{-1}$. The main band due to $\mathrm{Si}-\mathrm{O}$ and $\mathrm{Al}-\mathrm{O}$ vibrations ( $\mathrm{Si}-\mathrm{O}-\mathrm{Si}$ and $\mathrm{Al}-\mathrm{O}-\mathrm{Si}$ ), which is at $1062 \mathrm{~cm}^{-1}$ in the original fly ash, moves towards lower frequencies $\left(1000 \mathrm{~cm}^{-1}\right)$ in the geopolymers. The shift is interpreted as the result of $\mathrm{Al}$ penetration into the original structure of the Si-O-Si skeleton, similar to those bands which were detected in the zeolites. Following the hydrolyzation of the raw materials, a structural reorganization occurs in which aluminum ions are incorporated into the $\mathrm{SiO}_{4}$ tetrahedra, forming the Si-O-Al network. The aluminum ions act as a perturbation of silicate stretching vibrations, much as metal cations in other silicates such as sodium.

This region (about $1,062 \mathrm{~cm}^{-1}$ ) corresponds to the strongest peak in the unreacted raw material spectra and is therefore thought to be the result of unreacted raw material present in geopolymers. In samples exposed to the high post-thermal

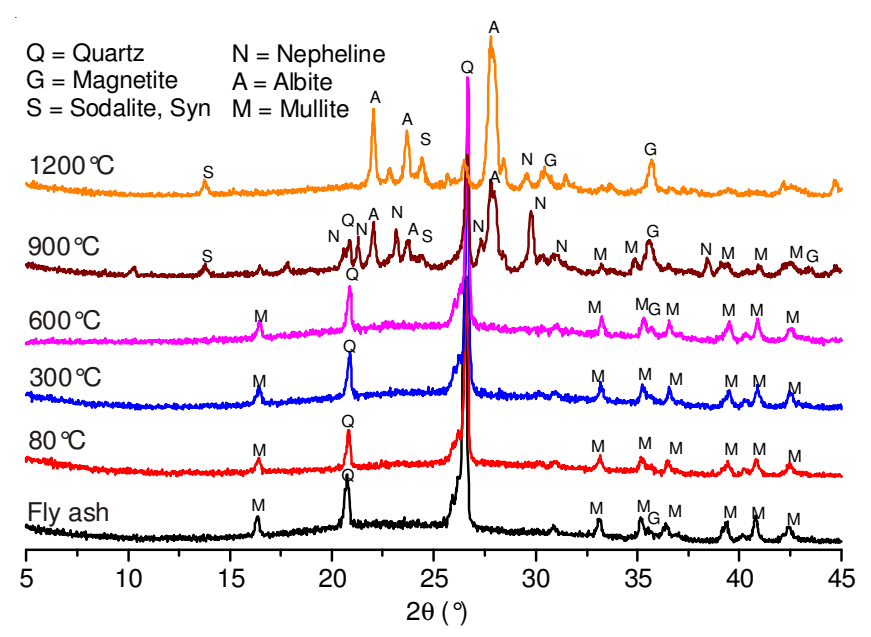

Fig. 2 Diffractogram for the post-thermal treatment samples

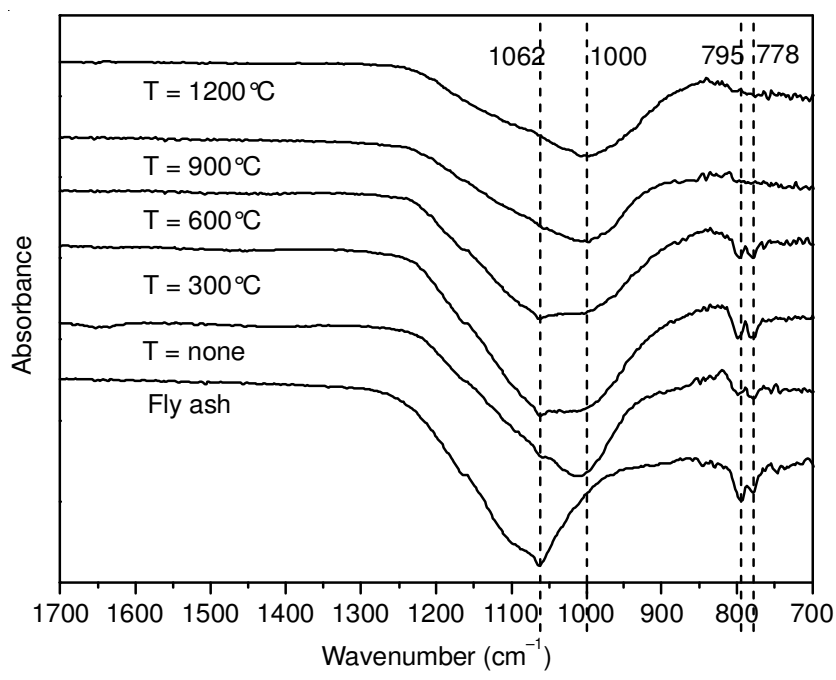

Fig. 3. FTIR spectra for the post-thermal treatment samples

temperatures $\left(900\right.$ and $1200{ }^{\circ} \mathrm{C}$ ), the band disappears. When geopolymer pastes were exposed to high post-thermal temperatures $\left(900\right.$ and $1200{ }^{\circ} \mathrm{C}$ ) and later cooled, the band at 800 $\mathrm{cm}^{-1}$, due to $\mathrm{AlO}_{4}$ vibrations, disappears.

The Netzsch STA 409 PC Luxx differential scanning calorimeter was used for combined TG/DTA. The samples were heated from $10-1000{ }^{\circ} \mathrm{C}$ at a rate of $10^{\circ} \mathrm{C} / \mathrm{min}$ in air. The analysis results obtained for the working samples are given in Fig. 4. The DTA curve for ordinary cement paste had two peaks, at around 130 and $450{ }^{\circ} \mathrm{C}$. The first was associated with the loss of adsorbed water and calcium-silicate-hydrates gel decomposition, whereas the second was attributed to the decomposition of $\mathrm{Ca}(\mathrm{OH})_{2}$. As for the TG curve, these 

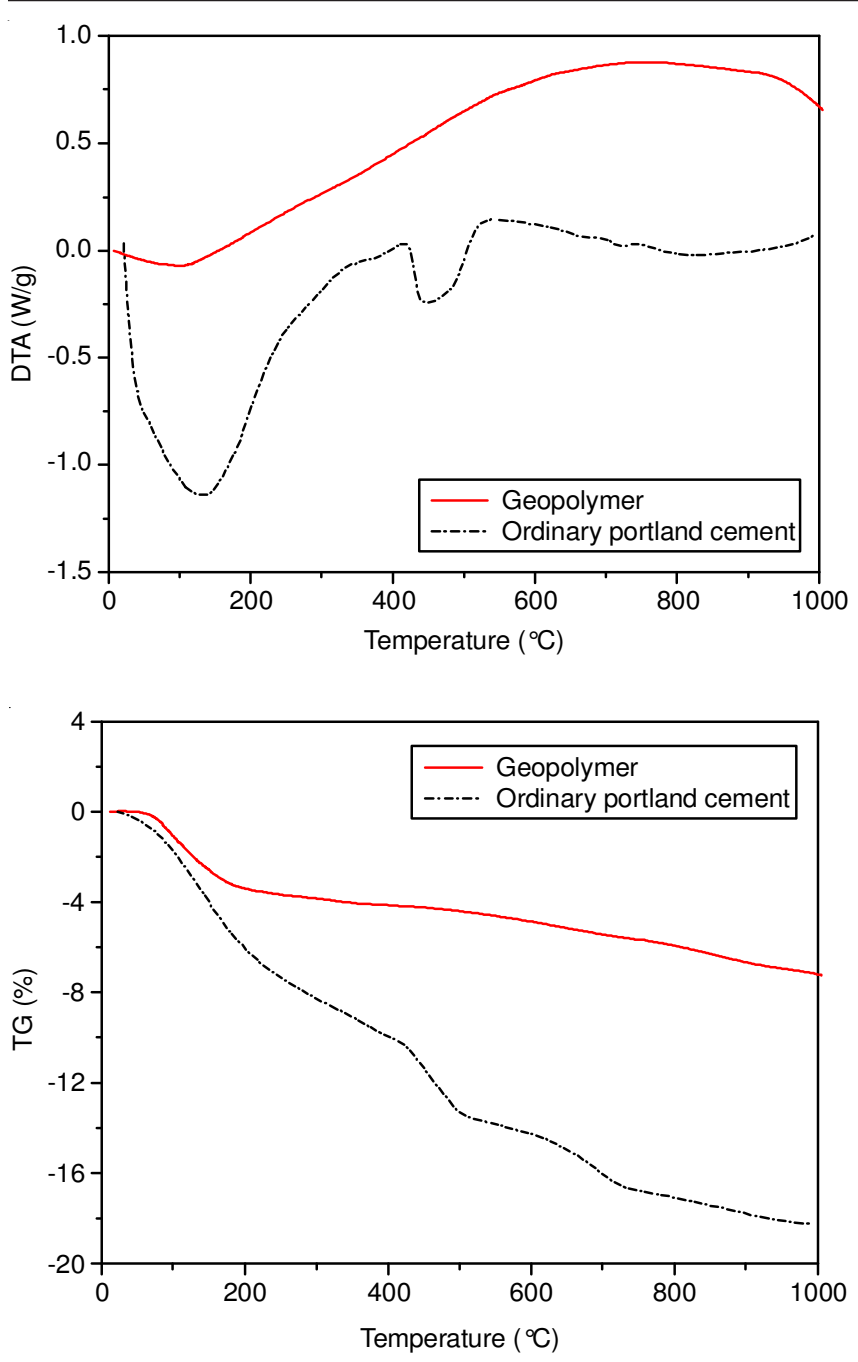

Fig. 4. DTA and TG curves for the samples

transformations involved weight loss. While the DTA curve for the alkali-activated fly ash pastes also had one wide peak at around $100{ }^{\circ} \mathrm{C}$, it was less intense than the portland cement signal. As with the portland cement, this peak was associated with the loss of adsorbed and combined water in gel.

The comparison of the TG curves for the two samples showed that the weight losses were visibly lower in the activated fly ash than in the portland cement paste (Fig. 4). The implication is that the fly ash sample does not readily decompose when exposed to high temperatures, so it would appear to be more structurally stable than portland cement at those temperatures.

The pore size distributions and cumulative volumes of intrusion resulting from the MIP testing of the geopolymer paste mixtures Nos. 6, 7 and 8 from Table-3. It was possible to verify that specimens with more $\mathrm{Na}_{2} \mathrm{O}$ contain smaller average pore diameters and porosities. (For example, when $\mathrm{Na}_{2} \mathrm{O}$ is 4,6 and $8 \%$ at $80{ }^{\circ} \mathrm{C}$, porosities are $0.33,0.30$ and $0.26 \mathrm{~mL}$ $\mathrm{mg}^{-1}$, respectively). Also, the higher firing temperature is, the larger the average pore diameters, but the smaller the porosities. This means that as the firing temperature increases, the compressive strengths of the geopolymer paste also increase and thus geopolymer pastes can be considered to have effec- tively changed to denser microstructures. Under firing temperature up to $900{ }^{\circ} \mathrm{C}$, pore diameters less than $1000 \mathrm{~nm}$ almost disappeared and new pores of which diameters ranged between 2000 and $4000 \mathrm{~nm}$ were obtained.

Firing the geopolymer above $300^{\circ} \mathrm{C}$ results in changes in its microstructure (Fig. 8). Unlike ordinary portland/pozzolanic cements, geopolymers do not form calcium-silicate-hydrates for matrix formation and strength, but utilize the polycondensation of silica and alumina precursors and a high alkali content to attain structural strength. The composition of the geopolymer is similar to natural zeolitic materials, but the microstructure is amorphous or semi-crystalline instead of crystalline. Scanning electron microscopy (SEM) was used to investigate the surface of fly ash before and after reacting with $\mathrm{NaOH}$ solution, there are the significant changes of microstructure after firing at $300-900{ }^{\circ} \mathrm{C}$ with pores up. However in case of firing at $1200{ }^{\circ} \mathrm{C}$, the development of these pores is possibly connected to decomposition of the material on heating.

\section{Conclusion}

The purpose of this study was to explore the effect of post-thermal treatment on the strength and microstructure of geopolymer composites. A series of geopolymer pastes were fabricated and tested. The residual compressive strength was measured under various temperature conditions. The microstructures of geopolymer composites were also analyzed to investigate the structural change. Based on the results of the present investigation, the following conclusions were drawn. The fly-ash-based geopolymer pastes tended to increase in strength with higher values of $\mathrm{SiO}_{2} / \mathrm{Na}_{2} \mathrm{O}$ mole ratio and temperature exposure up to $300-900{ }^{\circ} \mathrm{C}$. When exposed to $300{ }^{\circ} \mathrm{C}$, the samples showed no colour changes and remained dark grey. After exposure to $600{ }^{\circ} \mathrm{C}$, however, the colour changed to lighter grey. At $900{ }^{\circ} \mathrm{C}$, the samples' colour then impressively changed to red, accompanied by a ceramic-like surface texture. After exposure to high temperatures, hydroxysodalite formed in the initial geopolymer paste matrix during activation. In a sufficiently alkaline medium, hydroxysodalite is so thermodynamically stable that it crystallized quickly. In FTIR, following hydrolyzation, a structural reorganization occurs in the aluminum ions. The strongest peak in the unreacted raw material spectra is therefore thought to result from unreacted raw material present in the geopolymers. With exposing temperature up to $900^{\circ} \mathrm{C}$, the peak was located $1062-1000 \mathrm{~cm}^{-1}$. The micropore of which diameters less than $1000 \mathrm{~nm}$ almost disappear and new pores of which diameters ranging between 2000 and $4000 \mathrm{~nm}$ form at a high temperature. At high temperatures, the pores showed significant changes of microstructure. However when fired at $1200{ }^{\circ} \mathrm{C}$, the pores showed decomposition on heating.

\section{ACKNOWLEDGEMENTS}

This work was supported by the Nuclear Research \& Development of the Korea Institute of Energy Technology Evaluation and Planning (KETEP) grant funded by the Korea Government Ministry of Knowledge Economy (No. 20111010100030). 


\section{REFERENCES}

1. M. Xue, Y. Heichal, S. Chandra and J. Mostaghimi, J. Mater. Sci., 42, 9 (2007).

2. A. Palomo, M.W. Grutzeck and M.T. Blanco, Cement Concr. Res., 29, 1323 (1999)

3. A. Fernández-Jiménez and A. Palomo, 11th International Congress on the Chemistry of Cement, Durban, South Africa, vol. 3 (2003).

4. A. Fernández-Jiménez and A. Palomo, Fuel, 82, 2259 (2003).

5. P.V. Krivenko, Alkaline cements Alkaline Cements and Concretes, VipolStock Company, Kiev, edn 1, pp. 11-129 (1994).

6. A. Palomo, A. Fernández-Jiménez and M. Criado, Materiales de Construcción, 54, 77 (2004).

7. M. Criado, A. Palomo and A. Fernández-Jiménez, Fuel, 84, 2048 (2005).

8. J.S.J. van Deventer, J.L. Provis, P. Duxson and G.C. Lukey, J. Hazard. Mater., 139, 506 (2007).
9. T. Bakharev, Cement Concr. Res., 36, 1134 (2006).

10. D.L.Y. Kong and J.G. Sanjayan, Cem. Con. Com., 30, 986 (2008).

11. D.L.Y. Kong and J.G. Sanjayan, Cement Concr. Res., 40, 334 (2010).

12. D. Hardjito, S.E. Wallah, D.M.J. Sumajouw and B.V. Rangan, ACI Mater, 101, 6 (2004)

13. D.N.J. Sumajouw, D. Hardjito, S.E. Wallah and B.V. Rangan, Geopolymer Concrete for a Sustainable Future Proceedings Green Processing 2004-2nd International Conference on the Sustainable Processing of Minerals, Freemantle, Australia (2004).

14. D. Hardjito, S.E. Wallah, D.M.J. Sumajouw and B.V. Rangan, Brief Review of Development of Geopolymer Concrete Proceedings George Hoff Symposium on High Performance Concrete and Concrete for Marine Environment, Las Vegas, USA, pp. 63-72 (2004).

15. X.L. Guo, H.S. Shi and W.A. Dick, Cement Concr. Comp., 32, 142 (2010) 